\title{
Impact of Tax Incentives on Foreign Direct Investment Flow in Nigeria
}

\section{Halimatu Sa'adiya Ibrahim ${ }^{1}$, El-Maude Jibril Garba ${ }^{2}$, Maryam Muhammad ${ }^{2}$, Mohammad Mahmud Kakanda ${ }^{2}$, Abdulhamid Shehu ${ }^{1}$}

\author{
${ }^{1}$ Abubakar Tatari Ali Polytechnic \\ PMB 0094, Amadu Bello Way, Bauchi Town, Bauchi State, Nigeria \\ ${ }^{2}$ Modibbo Adama University of Technology, Yola \\ PMB 2076, Yola Adamawa State, Nigeria
}

DOl: $10.22178 /$ pos.78-5

JEL Classification: $\mathrm{H} 26$

Abstract. The growing pace of the globalisation process has triggered economic development, especially among developing nations. One of the immediate responses to this phenomenon is the increasing trend of Foreign Direct Investment flows among countries driven by some factors. This paper aimed at determining

Received 20.12.2021

Accepted 28.01.2022

Published online 31.01.2022 the impact of tax incentives (tax holiday and custom duty exemption) on Foreign Direct Investment inflow into Nigeria over the period 2008-2018. Using secondary data obtained from the Nigerian Investment Promotion Commission, Central Bank of Nigeria and Nigerian Customs Service, Driscoll-Kraay Standard Errors regression analysis was used via STATA version 14 to test the research hypothesis. The study's findings revealed that tax incentive has a positive and significant impact on Foreign Direct Investment inflow. Specifically, tax holiday has significant positive effect on FDI at $5 \%$ level of significance $(\beta=0.1578 ; t=3.99$; $p<0.05)$ while custom duties exemption reported significant positive effect on FDI at $1 \%$ level of significance $(\beta=0.2436 ; t=5.61 ; p<0.01)$. It is recommended that the government maintain and strengthen its policies on tax holidays and customs duties exemption to improve Foreign Direct Investment inflow, thereby developing the national economy.

(C) 2022 The Authors. This article is licensed under a Creative Commons Attribution 4.0 License @) (1)

Keywords: foreign direct investment; customs duty; tax holidays.

\section{INTODUCTION}

Foreign Direct Investment (FDI) is widely regarded as a potential source of funding growth and development for developed and developing countries. Governments across the globe are found to employ FDI strategies to accomplish their goals heavily. Consequently, this attracts researchers' attention, where many studies investigated the various strategies for effectively attracting FDI [31, 32]. Findings from these studies indicated that one of the popular strategies countries use in attracting FDI is tax incentives. The tax incentive is regarded as a form of exemption or exclusion from tax liability granted to investors or enterprises to encourage attracting investment in specific preferred sectors of the economy over a certain period. In another perspective, authors $[17,18]$ defined tax incentives as measures that provide for the more favourable tax treatment of certain activities or sectors compared to what is granted to the general in- dustry) tax incentives aid developed countries to promote export, research, and development.

On the other hand, it allows developing countries to attract FDI and improve economic conditions such as stock market performance, manufacturing, agriculture, and other vital sectors [25]. Author [20] submitted that the target of granting tax incentives is to encourage investment opportunities, especially in a situation where the existing tax system proves to be a barrier. Beyond economic benefits, tax incentives are also used to improve social welfare in health and education.

Nigeria, one of the developing countries, is not immune from the influences of internationalisation and globalisation engulfing the world. Over the years, the Nigerian government have drafted and implemented policies that affect various sectors of the nation's socio-economic development. One of such policies is the government's decision to revolutionise the manufacturing industry as a critical driver for economic growth through im- 
proved Gross Domestic Product (GDP) contribution. The policy introduced a new tax credit scheme to attract FDI inflow [3].

However, a literature review on the link between tax incentives and FDI flow reveals mixed results. Whereas some studies established a positive relationship between tax incentives and FDI flow [18], others reported adverse effects [1, 9]. Similarly, even though some studies explored the link between tax incentives and FDI flow in the Nigerian context, most studies were silent on custom duty exemption and tax holidays as a form of tax incentives. Moreover, the existing studies did not give much attention to the impact of tax holidays and custom duties exemption on FDI flow in the manufacturing sector of Nigeria [24]. Hence, this study investigates the impact of tax holidays and custom duty exemption on FDI flow in the listed manufacturing companies in Nigeria.

\section{Literature review}

Foreign Direct Investment is defined as the commitment of funds, resources, technology and or skill in an enterprise of another country to acquire a lasting interest and maximise profit in enterprises operating outside of the economy of the investor. In the development context, FDI is seen as an essential catalyst to the economic growth of developing countries. This follows from the fact that FDI has been found to increase technology and capital transfers, increase employment generation, and improve the economic conditions of host countries. FDI is an essential component for an effective international financial system. According to [25], growth in the use of FDI policies by both developed and developing countries to attract FDI flow has triggered the need for research to uncover the effectiveness of FDI in improving economic productivity and growth.

Determinants of FDI. Researchers and economists have widely studied the determinants of FDI flows, such as $[2,4,20]$. These studies found that FDI flows are influenced by market size, tax holiday, customs duty exemption, Inflation rate, Interest rate, openness rate, and political stability. Author [22] explained significant Spearman correlations between flows of FDI and market size, years of schooling, international trading flexibility, corporate governance, the distance between home and countries, and cost factors, including tax burden. Finding by [14] presented that the market size and trade openness as significant factors of FDI flows into Eastern and Central Europe

According to [30], the determinants of FDI can broadly be categorised into four different determinants: economic, social, political and policy determinants. The economic determinants include market size, GDP, per capita and purchasing power of the currency. The social determinants relate to human capital skills and overall host country development. The political determinants include frequency of government changes by type and period, number of internal armed attacks per period, degree of administrative efficiency and nationalism. The policy factors include legislative restrictiveness towards foreign companies and issues related to taxation [30].

Authors [5], using corporate tax rate, withholding tax, tax holiday and tax concessions as proxies of tax incentives and Random Effect econometric model as a tool of analysis, the study analysed a panel data covering the period 20002018 from forty African economies. It was found that lower corporate tax $(\beta=-0.784 ; t=-0.69$; $p=0.011$ ) significantly affect FDI. The result further revealed that countries with longer tax holidays $(\beta=0.254 ; t=2.41 ; p=0.017)$ and withholding $\operatorname{tax}(\beta=0.116 ; t=1.11 ; p=0.012)$ attract more FDI than those with shorter tax holidays and higher withholding tax. This implies that countries with lower corporate tax, more extended tax holidays, and lower withholding tax will attract high FDI flow.

Using data from twenty-two countries covering 1999 to 2018, authors [6] investigated the impact of tax incentives on FDI in Indonesia. The study used Fixed-effect, and Least Squares dummy variable analysis to determine and measure the direction and significance of the correlation between the tax incentives and other determinants with FDI. The results revealed that corporate income tax (used as a proxy of tax incentive) had a significant negative relationship with FDI flow at a 95\% confidence interval in the fixedeffect and Least Squares models. This suggests that lower corporate income tax regimes can attract investors to invest in a country, hence increasing FDI flow.

Authors [5] investigated the implication of taxation in FDI inflows in Pakistan. The study used Time Series data covering the period from 1985 to 2020 obtained from the World Development Indicator and the Economic Survey of Pakistan. 
The data analysis was conducted using AutoRegressive Distributed Lag (ARDL) and Error Correction Model (ECM) techniques. The result revealed that a higher tax rate had a significant adverse effect on FDI flow $(\beta=-0.17 ; t=-2.11$; $p=0.04$ ).

Author [23] adopted an Error Correction Model to analyse the effect of FDI determinants on FDI flow for 39 years. The finding revealed that past investment flows significantly stimulate the current investment inflows. Exchange rate and infrastructure were found to have a significant positive effect on FDI in Nigeria.

Conceptual framework. Many researchers researched the impact of a tax incentive on foreign direct investment, such as $[6,8,11,12,15,26]$. These studies used corporate tax rate, company income tax, capital allowances and nominal tax rate as the proxies for the tax incentive. However, only a few studies used tax holidays and custom duties exemption as proxies of tax incentives [2]. Hence, this study adopts tax holiday and customs duties exemption as proxies of tax incentive and the following hypotheses are postulated:

$\mathrm{HO}_{1}$ : tax holiday has no significant effect on foreign direct investment flow.

$\mathrm{HO}_{2}$ : custom duty exemption has no significant effect on foreign direct investment flow.

The research framework of the study is given in Figure 1.

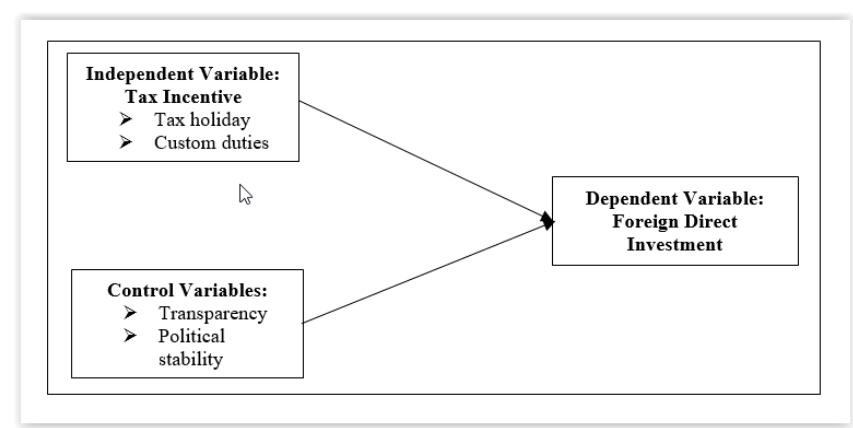

Figure 1 - Research Framework

\section{METHODOLOGY}

A survey research strategy using ex-post factor design was adopted in examining the impact of the explanatory variables in the study. Secondary data covering the period 2008-2018 obtained from the Nigerian Investment Promotion Commission, Central Bank of Nigeria and Nigerian Customs Service was used in the analysis. Foreign direct investment flow was used as the dependent variable in the study. FDI was measured using the value of Naira (N) accrued to the sectors under review as [35]. Tax incentives were used as the independent variable. Tax holidays and custom duties exemption are used as proxies of the independent variables and are measured in line with the approach adopted in $[2,7,18,29$, 35].

Transparency and political stability were used as control variables in the study. Transparency was measured using the transparency index based on CPI information package 2016, where countries are profiled on an index 0-10 with 0 representing highly corrupt status and 10 representing highly transparent status [27]. On the other hand, political stability was measured by a proxy of the average political freedom and civil liberty based on a range of 1-7, where 1 and 7 indicate good and weak political stability, respectively.

Data analysis was conducted using the DriscollKraay Standard Errors regression. STATA version 14 was used for the analysis. Justification for the use of this variant of regression emanates from the fact that the data violates some of the assumptions of the conventional multiple regression. The model was operationalised as follows:

$$
\mathrm{FDI}=\beta_{0}+\beta_{1} \mathrm{TH}_{\mathrm{it}}+\beta_{2} \mathrm{CDE}_{\mathrm{it}}+\beta_{3} \mathrm{~T}_{\mathrm{it}}+\beta_{4} \mathrm{PS}_{\mathrm{it}}+\mathrm{e}_{\mathrm{it}}
$$

where FDI - Foreign direct investment, TH - Tax holidays, CDE - Custom duties exemptions, $\mathrm{T}$ Transparency, PS - Political Stability, $\beta_{0}-$ Regression intercept, $\beta_{1}, \beta_{2}$ - Parameters to be estimated, e - Error term.

\section{RESULTS AND DISCUSSION}

Descriptive Statistics. Descriptive statistics usually describe samples of subjects in terms of variation or combination of variables [28]. A descriptive statistic is the first step of the data screening process as it provides a description and summary statistic of the data to be analysed. Table 1 shows the mean, standard deviation, minimum, maximum, skewness and kurtosis of the variables in this study. 
Table 1 - Descriptive Statistics

\begin{tabular}{|l|c|c|c|c|c|c|}
\hline \multicolumn{1}{|c|}{ Variables } & Mean & Std. Dev. & Min. & Max. & Skewness & Kurtosis \\
\hline FDI & 0.2140 & 0.31 & 0.0005 & 1.4302 & 1.23 & 6.3 \\
\hline Tax Holiday & 0.6667 & 0.48 & 0 & 1.0000 & -0.71 & 1.50 \\
\hline Custom Du_Exe & 0.9290 & 0.30 & 0.2570 & 1.2980 & -0.83 & 2.95 \\
\hline Transparency & 2.5000 & 0.24 & 2.0000 & 2.9000 & -0.43 & 2.72 \\
\hline Political Stability & 4.5454 & 0.51 & 4.0000 & 5.0000 & -0.18 & 1.03 \\
\hline
\end{tabular}

Notes: FDI - Foreign Direct Investment; Custom Du_Exe - Custom Duties Exempted.

The reported mean and standard deviation of FDI (M=0.2140; $S D=0.31)$ indicated that, on average, the value of FDI flow into the country during the period under review was N214,000,000.00 (conversion rate in 100 million) with a variation of N31,000,000.00 across the sectors. The descriptive statistics for tax holiday reported mean and standard deviation of $(\mathrm{M}=0.6667 ; \mathrm{SD}=0.4800)$ with a minimum value of 0 (no tax holiday) and a maximum weight of ' 1 ' (tax holiday present). This implies that about $67 \%$ of the studied sectors enjoyed tax holidays under review. Moreover, descriptive statistics show that custom duties exemption reported a mean and standard deviation of $(\mathrm{M}=0.9290$; $\mathrm{SD}=0.2570$ ). This implies that custom duties exemption over the period under review amounted to an average of N92,900,000,000.00 (conversion rate in 100 billion).

Concerning the control variables used in the study, the descriptive statistics result showed that transparency has a mean and standard deviation of $(\mathrm{M}=2.5 ; \mathrm{SD}=0.24)$ with minimum and maximum values of 2 and 2.9, respectively. This implies that Nigeria was rated low in the transparency index during the review. The descriptive statistics for political stability reported a mean and standard deviation of $(\mathrm{M}=4.5454$; $\mathrm{SD}=0.5100$ ). In contrast to the transparency index, the political stability index portrays that $\mathrm{Ni}$ geria was rated well over review.

Driscoll-Kraay Regression Results. Driscoll-Kraay regression was used to measure the impact of tax incentives on FDI inflow in Nigeria during the study timeline. The use of Driscoll-Kraay regression is on the premise that the data in this study suffer from heteroscedasticity and serial correlation problems (results not shown here). According to [13], Driscoll-Kraay regression is a nonparametric covariance matrix estimator that produces heteroscedasticity consistent standard errors robust to very general forms of spatial and temporal dependence. Hence, Stata has a long tradition of providing the option to estimate common mistakes that are "robust" to specific violations of the underlying econometric model. STATA version 14 was used in executing DriscollKraay Standard Errors regression, and the result is presented in Table 2.

Table 2 - Driscoll-Kraay Standard Errors Regression

\begin{tabular}{|l|l|l|l|}
\hline & \multicolumn{3}{|c|}{ Driscoll-Kraay } \\
\hline Variables & $\beta$ & t-stat. & $\mathrm{p}>\mathrm{t}$ \\
\hline Intercept & 0.3506 & 2.25 & $0.048^{2}$ \\
\hline Tax Holiday & 0.1578 & 3.99 & $0.003^{3}$ \\
\hline $\begin{array}{l}\text { Custom Duties } \\
\text { Exemption }\end{array}$ & 0.2436 & 5.61 & $0.000^{3}$ \\
\hline Transparency & 0.0082 & 0.24 & 0.817 \\
\hline Political Stability & -0.1075 & -3.80 & $0.003^{3}$ \\
\hline Observations & Observations & 33 & \\
F(4, 28) & Group & 3 & \\
Prob $>\mathrm{F}$ & $\mathrm{F}(4,10)$ & 11.62 & \\
$\mathrm{R}^{2}$ & Prob $>\mathrm{F}$ & 0.00093 \\
Adj. $\mathrm{R}^{2}$ & $\mathrm{R}^{2}$ & 0.1362 \\
\hline
\end{tabular}

Notes: ${ }^{2}$ and ${ }^{3}$ imply statistical significance on the $5 \%$ and $10 \%$ level, respectively

The result shows that the model has an $\mathrm{R}^{2}$ value of 0.1362 . This portrays that the explanatory variables in this study explain $13.62 \%$ of the variations in FDI inflow during the period under review. Equally important, the model is significantly based on $F(4,10) ; p<0.01)$, thus indicating the validity and goodness of fit. Specifically, the regression result demonstrates that Tax Holiday has a significant positive effect on foreign direct investment at $5 \%$ level of significance $(\beta=0.1578$; $t=3.99 ; p<0.05)$. This specifies that any increase in tax holiday by one would increase foreign direct investment by 0.1578 (N157,800,000). However, this result has contradicted the null hypothesis of this study, which states that "tax holiday does not have a significant impact on FDI inflow into the Nigerian economy. Hence, the null hypothesis one $\left(\mathrm{HO}_{1}\right)$ of this study is not sup- 
ported. The result agrees with previous studies such as [24], which found that tax incentives (capital allowances incentives, value-added tax incentives, capital gains tax incentives) among others had a significant relationship with FDI inflow. However, the result contradicts studies like that of [10], who found that tax incentives had no significant effect on FDI inflow.

Similarly, Table 2 shows that custom duties exemption significantly impacts foreign direct investment at a $1 \%$ level of significance $(\beta=0.2436$; $t=5.61 ; p<0.01)$. This means that a unit change in customs duties exemption would increase 0.2436 (N24.360 billion) in FDI flow. Thus, the null hypothesis two of that stated that custom duties exemptions do not have a significant impact on foreign direct investment inflow into the Nigerian economy is not supported. The result confirms the findings of previous studies such as $[2,16,24]$, who all established that tax incentives have a significant positive impact on FDI flow. On the other hand, this result contradicts that of [10, 21]. Their separate studies found no significant relationship between tax incentives and FDI flow.

Transparency reported a positive but insignificant effect on foreign direct investment $(\beta=0.0082 ; t=0.24 ; p>0.10)$. In contrast, however, political stability reported a negative but statistically significant effect on foreign direct investment at a $1 \%$ significance level $(\beta=-0.1075 ; t=-$ 3.80; $\mathrm{p}<0.01)$. This implies that a unit decrease in political stability would result in a decrease in FDI flow. However, this result is odd but is in line with the findings of [10].

Robustness Test. A robustness test is usually conducted to examine the consistency of statistical results obtained. Therefore, a robustness test was performed to investigate the surface of this study's regression result and findings. To this end, the sample was divided based on three groups of sectors used in this study; (1) the Manufacturing sector, (2) the Agricultural sector, and the Construction sector. Table 3 shows the result of Driscoll-Kraay Standard Errors regression under the three groups.

From Table 3, the model is said to be fit and valid since the probability values under the three sectors are significant. The model is explicitly significant at a $1 \%$ level of significance under the manufacturing and construction sectors, while at a $5 \%$ level of significance under the agricultural sector. This result is consistent with that of the main regression result, and as such, the model is considered good and valid. Moreover, the $\mathrm{R}^{2}$ values are $0.5776(57.76 \%), 0.1783$ (17.83\%), and 0.5116 (51.16\%) for manufacturing, agricultural, and construction sectors respectively. Meaning that the explanatory variables accounted for $57.76 \%, 17.83 \%$, and $51.16 \%$ of the variation in foreign direct investment under manufacturing, agriculture, and construction sectors, respectively.

Table 3 - Driscoll-Kraay Standard Errors Regression for three groups

\begin{tabular}{|l|c|c|c|c|c|c|}
\hline \multirow{2}{*}{ Variables } & \multicolumn{2}{|c|}{ Manufacturing sector } & \multicolumn{2}{c|}{$\begin{array}{c}\text { Agricultural } \\
\text { sector }\end{array}$} & \multicolumn{2}{c|}{$\begin{array}{c}\text { Construction } \\
\text { sector }\end{array}$} \\
\cline { 2 - 7 } & Coef. & t-stat & Coef. & t-stat & Coef. & t-stat \\
\hline Constant & 0.7637 & $1.89^{*}$ & 0.0989 & 0.94 & 0.4330 & $1.744^{*}$ \\
\hline Tax Holiday & 0.4277 & $2.79^{* *}$ & -0.0005 & -0.01 & 0.0844 & $3.44^{* * *}$ \\
\hline Custom Du_Exe & 0.6374 & $4.01^{* * *}$ & 0.0937 & $1.47^{*}$ & 0.1685 & $4.79^{* * *}$ \\
\hline Transparency & 0.1415 & 0.71 & -0.0271 & -0.31 & -0.2032 & $-4.94^{* * *}$ \\
\hline Political Stability & -0.3318 & $-5.33^{* * *}$ & -0.0108 & -0.21 & -0.0163 & -0.43 \\
\hline Observations & 11 & & 11 & & 11 & \\
\hline Groups & 1 & & 1 & & 1 & \\
\hline $\mathrm{F}(4,10)$ & 12.28 & & 4.11 & & 48.45 & \\
\hline Prob>F & 0.0007 & & 0.0319 & & 0.0000 & \\
\hline $\mathrm{R}^{2}$ & 0.5776 & & 0.1783 & & 0.5116 & \\
\hline
\end{tabular}

Notes: ${ }^{*}, \star \star$, and $\star \star \star$ implies statistical significance on $10 \%, 5 \%$ and $1 \%$ level, respectively

Additionally, the result from Table 3 depicts that tax holiday has a significant positive effect on FDI at $10 \%$ and $5 \%$ in manufacturing $(\beta=0.7637$; $t=2.79 ; \quad p<0.10)$ and construction sectors $(\beta=0.04330 ; t=3.44 ; p<0.05)$ respectively. This result is consistent with that of the main regres- 
sion result. However, the tax holiday is found to have an insignificant negative effect on foreign direct investment in the agricultural sector $(\beta=0.0989 ; t=-0.01 ; p>0.10)$. Furthermore, custom duties exemption has a significant positive effect on foreign direct investment at $1 \%$ level of significance in the manufacturing $(\beta=0.6374$; $t=4.01 ; \quad p<0.05)$ and construction $(\beta=0.1685$; $t=4.79 ; p<0.10$ ) sectors respectively and $10 \%$ statistical significance in the agricultural sector $(\beta=0.0937 ; \mathrm{t}=1.47 ; \mathrm{p}<0.10)$. These results are consistent with the main result of the DriscollKraay Standard Errors regression presented in Table 2.

The sectoral Driscoll-Kraay regression results in Table 3 indicate that for the control variables in this study, transparency has an insignificant positive effect on foreign direct investment $(\beta=0.1415 ; t=0.71 ; p>0.10)$ under manufacturing sector, insignificant negative effect on FDI $(\beta=-$ 0.0271 ; $\mathrm{t}=-0.31 ; \mathrm{p}>0.10$ ) under agricultural sector, while having a significant negative effect on FDI $(\beta=-0.2032 ; \mathrm{t}=-4.94 ; \mathrm{p}<0.01)$ under construction sector.

On the other hand, political stability has a significant negative effect on FDI $(\beta=-0.3318 ; t=-5.33$; $p<0.01)$. However, it shows an insignificant negative impact on FDI under agricultural sector $(\beta=-$ $0.0108 ; t=-0.21 ; p>0.10)$ and construction sector $(\beta=-0.0163 ; t=-0.43 ; \mathrm{p}>0.10)$ as well. Arguably, it can then be concluded that based on the sectoral Driscoll-Kraay regression result in Table 3, the main regression is consistent, except the explanatory variables under the agricultural sector, which showed inconsistency.

The objective of this study was to examine the impact of tax incentives on foreign direct investment (FDI) in Nigeria. Under attaining this objective, Driscoll-Kraay regression was utilised where the study found that tax holiday and custom duty exemption have a significant positive effect on FDI. Specifically, tax holiday as a proxy of tax incentive positively and significantly impacted FDI, which goes in line with the [2]. This indicates that tax holiday is an essential determi- nant of FDI in Nigeria because an increase in tax holiday is expected to increase foreign direct investment inflow into the Nigerian economy.

Additionally, the study found that custom duties exemption, another proxy for the tax incentive, has a significant positive effect on FDI. This indicates that any increase in custom duties exemptions may increase FDI inflow into the Nigerian economy. The finding is in line with $[7,24]$, who found that custom duties exemption has no significant effect on FDI inflow.

Similarly, the robustness test conducted on a sectoral basis further confirmed the consistency of the main Driscoll-Kraay Standard Errors regression result. The result revealed that tax incentives as proxies by tax holiday and custom duties exemptions have a significant positive effect on FDI under the manufacturing and construction sector, but with a partial significant positive impact (custom duties exemption only) on FDI under the agricultural sector. This result aligns with the finding of [7] tax holidays have a significant impact on the manufacturing industry while custom duty exemption has a substantial effect on the construction, electricity, and water supply sectors in the study.

\section{CONCLUSIONS}

Tax incentives have a significant positive effect on foreign direct investment inflow into the $\mathrm{Ni}$ gerian economy. Specifically, the proxies of the tax incentive, tax holiday and custom duties exemptions showed a significant positive effect on foreign direct investment inflows into the Nigerian economy. The Nigerian government should maintain the elegant tax holiday alongside custom duties exemption and possibly device means of improving them because empirical evidence showed how the US firm realised higher return on capital invested over and above European investment in home countries. The improvement may also improve foreign direct investment inflow into the Nigerian economy.

\section{REFERENCES}

1. Abille, A. B., Mpuure, D. M.-N., Wuni, I. Y., \& Dadzie, P. (2020). Modelling the synergy between fiscal incentives and foreign direct investment in Ghana. Journal of Economics and Development, 22(2), 325-334. doi: 10.1108/jed-01-2020-0006 
2. Adams, S., \& Opoku, E. E. O. (2015). Foreign direct investment, regulations and growth in subSaharan Africa. Economic Analysis and Policy, 47, 48-56. doi: 10.1016/j.eap.2015.07.001

3. Aganga, 0. 0. (2014, October 6). Nigeria's manufacturing sector in 2012. Daily Independent.

4. Anyanwu, J. (2012). Why Does Foreign Direct Investment Go Where It Goes? New Evidence from African Countries. Annals of Economics and Finance, 13(2), 425-462.

5. Appiah-Kubi, S. N. K., Malec, K., Phiri, J., Maitah, M., Gebeltová, Z., Smutka, L., ... Sirohi, J. (2021). Impact of Tax Incentives on Foreign Direct Investment: Evidence from Africa. Sustainability, 13(15), 8661. doi: 10.3390/su13158661

6. Asiedu, E. (2006). Foreign Direct Investment in Africa: The Role of Natural Resources, Market Size, Government Policy, Institutions and Political Instability. The World Economy, 29(1), 63-77. doi: 10.1111/j.1467-9701.2006.00758.x

7. Bora, S. M. (2013). The effectiveness of tax incentives in attracting foreign direct incentives to Ethiopia (Master's thesis). Retrieved from https://thesis.eur.nl/pub/15430/SBora_moodledata_temp_turnitintool_1049225358._60_1384 340914_1972.pdf

8. Coelho, B., \& Gallagher, K. (2010). Capital controls and 21st century financial crises: evidence from Colombia and Thailand. Retrieved from https://scholarworks.umass.edu/cgi/viewcontent.cgi?article=1181\&context=peri_workingpape rs

9. Fowowe, B. (2013) Financial liberalisation in Sub-Saharan Africa: What do we know? Journal of Economic Survey, 27, 1-37.

10. George, T., \& Bariyima, D. (2015). Tax Incentives and Foreign Direct Investment in Nigeria. Journal of Economics and Finance, 6(5), 10-20

11. Githaiga, I. W. (2013). The impact of tax incentives on foreign direct investments inflows of firms listed at the Nairobi Securities Exchange (Doctoral dissertation). Retrieved from http://erepository.uonbi.ac.ke/handle/11295/59641

12. Haiyambo, E. (2013). Tax Incentives and Foreign Direct Investment: The Namibian Experience (Doctoral dissertation). Retrieved from https://ir.nust.na/xmlui/bitstream/handle/10628/413/Haiyambo.Tax\%20Incentives\%20and \%20Foreign\%20Direct\%20Investment.\%20The\%20Nam\%20experience.pdf?sequence=1\&isAl lowed $=\mathrm{y}$

13. Hoechle, D. (2007). Robust Standard Errors for Panel Regressions with Cross-Sectional Dependence. The Stata Journal: Promoting Communications on Statistics and Stata, 7(3), 281312. doi: $10.1177 / 1536867 \times 0700700301$

14. Holland, D., \& Pain, N. (2000). The Diffusion of Innovations in Central and Eastern Europe: a study of the Determinants and Impact of Foreign Direct Investment. Retrieved from https://www.researchgate.net/publication/5200474_The_Diffusion_of_Innovations_in_Central_ and_Eastern_Europe_A_Study_of_the_Determinants_and_Impact_of_Foreign_Direct_Investment

15. Imbayi, G. (2013). An investigation of the effects taxation on foreign direct investment in Kenya (Doctoral dissertation). Retrieved from http://erepository.uonbi.ac.ke/bitstream/handle/11295/59671/An\%20Investigation\%200f\% 20The\%20Effects\%20Taxation\%200n\%20Foreign\%20Direct\%20Investment\%20In\%20Keny a? sequence $=3$

16. Kimberley, Y. Z. (2009). How Do Tax Incentives Affect the Composition of Foreign Direct Investment (FDI) in North-East Asia (Masters thesis). Retrieved from https://openrepository.aut.ac.nz/bitstream/handle/10292/756/ZuoK.pdf?sequence=4\&isAllo wed $=\mathrm{y}$ 
17. Klemm A. (2010). Causes, benefits and risks of tax incentives. Retrieved from

https://www.imf.org/en/Publications/WP/Issues/2016/12/31/Causes-Benefits-and-Risks-ofBusiness-Tax-Incentives-22628

18. Klemm, A., \& Parys, S. V. (2009). Empirical Evidence on the Effects of Tax Incentives. Retrieved from www.imf.org/external/pubs/ft/wp/2009/wp09136.pdf

19. Kransdorff, M. (2016). Tax incentive on foreign direct investment in South Africa. The Journal for Sustainable Development, 3(1), 68-84.

20. Madzivanyika, E. (2016). Customs duty incentives and their effects on customs revenue mobilization: the case of Zimbabwe (2009-2014). Public and Municipal Finance, 5(1), 6-13. doi: 10.21511/pmf.05(1).2016.01

21. Million, T. J., Azime, A. H., \& Gollagori, R. (2016). The Relationship between FDI flows and Tax Revenues in Ethiopia: an Evidence based on ARDL Model with a Structural Break. Retrieved from https://www.researchgate.net/publication/307639333_The_Relationship_between_FDI_flows_ and_Tax_Revenues_in_Ethiopia_an_Evidence-based_on_ARDL_Model_with_a_Structural_Break

22. Nunnenkamp, P. (2001). Foreign direct investment in developing countries: What policymakers should not do and what economists don't know. Retrieved from https://www.econstor.eu/bitstream/10419/2616/1/kd380.pdf

23. Okpara, G. (2012). An Error Correction Model Analysis of the Determinant of Foreign Direct Investment: Evidence from Nigeria. Retrieved from https://mpra.ub.unimuenchen.de/36676/1/MPRA_paper_36676.pdf

24. Olaleye, M., Riro, G., \& Memba, F. (2016). Effect of reduced company income tax incentives on foreign direct investment in listed Nigerian manufacturing companies. European Journal of Business, Economics and Accountancy, 4(1), 39-54.

25. Ondabu, I., Willy, M., \& Kisaka, E. (2016). Effects of tax incentives on performance of listed firms in Kenya. International Journal of Scientific and Research Publications, 6(7), 678-690.

26. Rusike. (2007). Trends and determinants of inward foreign direct investment to South Africa (Masters thesis). Retrieved from http://vital.seals.ac.za:8080/vital/access/manager/Repository/vital:995?site_name=GlobalVie w

27. Shakirat Adepeju, B. (2012). The Impact of Tax Incentives on Foreign Direct Investment in the Oil and Gas Sector in Nigeria. Journal of Business and Management, 6(1), 1-15. doi: 10.9790/487x0610115

28. Tabachnick, B., \& Fidell, L. (2007). Using Multivariate Statistics (5th ed.). New York: Pearson Education.

29. Tuomi, K. (2012). Review of Investment Incentives. Best Practice in Attracting Investment. Retrieved from https://www.theigc.org/wp-content/uploads/2012/06/Tuomi-2012-Working-Paper.pdf

30. Ugochukwu, U., Amah, O., \& Onoh, J. O. (2013). The impact of foreign direct investment on the Nigerian economy. European Journal of Business and Management, 5(2), 25-33.

31. UNCTAD, (2009). World Investment Report 2009. Retrieved from https://unctad.org/system/files/official-document/wir2009_en.pdf

32. UNCTAD. (2005). World Investment Report 2005. Retrieved from https://unctad.org/system/files/official-document/wir2005_en.pdf

33. Wilson, J. D. (1991). Tax competition with interregional differences in factor endowments. Regional Science and Urban Economics, 21(3), 423-451. doi: 10.1016/0166-0462(91)90066-v

34. Yang, J. Y. Y., Groenewold, N., \& Tcha, M. (2000). The Determinants of Foreign Direct Investment in Australia. Economic Record, 76(232), 45-54. doi: 10.1111/j.1475-4932.2000.tb00004.x 
35. Ye, J., \& Wang, J. (2014). Effects of FDI on China's technological innovation: An empirical test based on 2002-2011 panel data of Jiangsu Province. Journal of International Trade, 1, 131-138. 